\title{
Altered purinergic signaling in uridine adenosine tetraphosphate-induced coronary relaxation in swine with metabolic derangement
}

\author{
Zhichao Zhou $^{1,2}$. Oana Sorop ${ }^{1}$ - Vincent J. de Beer ${ }^{1}$ - Ilkka Heinonen ${ }^{1,3,4}$. \\ Caroline Cheng ${ }^{1,5}$ • A. H. Jan Danser ${ }^{6}$. Dirk J. Duncker ${ }^{1}$ • Daphne Merkus ${ }^{1}$ (I)
}

Received: 17 February 2017 / Accepted: 24 April 2017 /Published online: 24 May 2017

(C) The Author(s) 2017. This article is an open access publication

\begin{abstract}
We previously demonstrated that uridine adenosine tetraphosphate $\left(\mathrm{Up}_{4} \mathrm{~A}\right)$ induces potent and partially endothelium-dependent relaxation in the healthy porcine coronary microvasculature. We subsequently showed that $\mathrm{Up}_{4} \mathrm{~A}$-induced porcine coronary relaxation was impaired via downregulation of $\mathrm{P} 1$ receptors after myocardial infarction. In view of the deleterious effect of metabolic derangement on vascular function, we hypothesized that the coronary vasodilator response to $\mathrm{Up}_{4} \mathrm{~A}$ is impaired in metabolic derangement, and that the involvement of purinergic receptor subtypes and endothelium-derived vasoactive factors (EDVFs) is altered. Coronary small arteries, dissected from the apex of healthy swine and swine 6 months after induction of diabetes with streptozotocin and fed a high-fat diet, were mounted on wire myographs. $\mathrm{Up}_{4} \mathrm{~A}\left(10^{-9}-10^{-5} \mathrm{M}\right)$ -
\end{abstract}

Daphne Merkus

d.merkus@erasmusmc.nl

1 Division of Experimental Cardiology, Department of Cardiology, Thoraxcenter, Cardiovascular Research School COEUR, Erasmus MC, University Medical Center Rotterdam, PO Box 2040, 3000 CA Rotterdam, The Netherlands

2 Present address: Unit of Cardiology, Department of Medicine, Karolinska University Hospital, Karolinska Institutet, Stockholm, Sweden

3 Turku PET Centre, University of Turku and Turku University Hospital, Turku, Finland

4 Department of Clinical Physiology and Nuclear Medicine, University of Turku, Turku, Finland

5 Department of Nephrology \& Hypertension, University Medical Center Utrecht, Utrecht, The Netherlands

6 Division of Pharmacology, Department of Internal Medicine, Erasmus MC, University Medical Center Rotterdam, Rotterdam, The Netherlands induced coronary relaxation was maintained in swine with metabolic derangement compared to normal swine, despite impaired endothelium-dependent relaxation to bradykinin and despite blunted $\mathrm{P} 2 \mathrm{X}_{7}$ receptor and NO-mediated vasodilator influences of $\mathrm{Up}_{4} \mathrm{~A}$. Moreover, a thromboxanemediated vasoconstrictor influence was unmasked. In contrast, an increased $\mathrm{Up}_{4} \mathrm{~A}$-mediated vasodilator influence via $\mathrm{P}_{2} \mathrm{Y}_{1}$ receptors was observed, while, in response to $\mathrm{Up}_{4} \mathrm{~A}$, cytochrome $\mathrm{P}_{450} 2 \mathrm{C} 9$ switched from producing vasoconstrictor to vasodilator metabolites in swine with metabolic derangement. Coronary vascular expression of $\mathrm{A}_{2 \mathrm{~A}}$ and $\mathrm{P} 2 \mathrm{X}_{7}$ receptors as well as eNOS, as assessed with realtime PCR, was reduced in swine with metabolic derangement. In conclusion, although the overall coronary vasodilator response to $\mathrm{Up}_{4} \mathrm{~A}$ was maintained in swine with metabolic derangement, the involvement of purinergic receptor subtypes and EDVF was markedly altered, revealing compensatory mechanisms among signaling pathways in $\mathrm{Up}_{4} \mathrm{~A}$-mediated coronary vasomotor influence in the early phase of metabolic derangement. Future studies are warranted to investigate the effects of severe metabolic derangement on coronary responses to $\mathrm{Up}_{4} \mathrm{~A}$.

Keywords $\mathrm{Up}_{4} \mathrm{~A} \cdot$ Coronary relaxation $\cdot$ Purinergic receptor . Thromboxane $\cdot$ Cytochrome $\mathrm{P}_{450} 2 \mathrm{C} 9 \cdot$ Metabolic derangement

\section{Introduction}

Diabetes mellitus is the most prevalent endocrine disorder worldwide, and diabetes mellitus and associated metabolic derangement constitute an important risk factor for development of cardiovascular disease including atherosclerosis and diabetic heart disease. The latter is the consequence not only 
of proximal obstructive coronary artery disease but also of coronary microvascular disease $[1,2]$. Endothelial dysfunction is an important determinant of altered vascular reactivity and plays a major role in the etiology of diabetes-induced macrovascular and microvascular complications [3, 4]. This endothelial dysfunction encompasses an imbalance between the secretion of endothelium-derived relaxing factors (such as NO and prostacyclin) and endothelium-derived constricting factors (such as endothelin and thromboxane) [4, 5].

Uridine adenosine tetraphosphate $\left(\mathrm{Up}_{4} \mathrm{~A}\right)$ was initially identified as an endothelium-derived vasoconstrictor, exerting its constrictor influence in various vascular beds [6-10]. The vasoconstriction was shown to involve the generation of thromboxane [11] and reactive oxygen species [12]. A subsequent study reported that $\mathrm{Up}_{4} \mathrm{~A}$-mediated vascular contraction was enhanced in renal, basilar, and femoral arteries of DOCAsalt-induced hypertensive rats compared to normal rats [9]. Moreover, $\mathrm{Up}_{4} \mathrm{~A}$-induced contraction was increased in renal arteries from rats with type 2 diabetes through activation of the cyclooxygenase-thromboxane pathway [13], suggesting that disease states, including diabetes-associated metabolic derangement [14], may aggravate $\mathrm{Up}_{4} \mathrm{~A}$-mediated vasoconstriction.

Similar to other extracellular nucleotides, $\mathrm{Up}_{4} \mathrm{~A}$ exerts its vasomotor influence by binding to purinergic receptors [15, 16]. The purinergic receptor family consists of P1 (adenosine receptors) and $\mathrm{P} 2$ receptor subtypes that can be further divided into P2X and P2Y receptors [17]. There is evidence from rodent models and humans that vascular purinergic signaling is altered in metabolic disorders [18]. The vasoconstrictor response to ATP, a putative P2 receptor agonist [19], was increased, while in preconstricted mesenteric arteries from rats with diabetes, the vasodilator response to ATP was decreased $[20,21]$. Similarly, the vasodilation to ATP, UTP, and adenosine was impaired in femoral arteries of patients with type 2 diabetes [22].

Contrary to the vasoconstrictor effect of $\mathrm{Up}_{4} \mathrm{~A}$ in most vascular beds [6-10], $\mathrm{Up}_{4} \mathrm{~A}$ acts as a potent vasodilator in the coronary microcirculation [15]. We recently demonstrated that $\mathrm{Up}_{4} \mathrm{~A}$-induced coronary relaxation was blunted in swine after myocardial infarction possibly via downregulation of $\mathrm{P} 1$ receptors [23]. In the present study, we tested the hypothesis that the coronary vasodilator response to $\mathrm{Up}_{4} \mathrm{~A}$ is also impaired in swine with metabolic derangement (diabetes mellitus and dyslipidemia) and investigated the involvement of altered signaling through purinergic receptor subtypes and endothelium-derived vasoactive factors (EDVFs). Our findings surprisingly demonstrate that, despite the presence of endothelial dysfunction, the coronary vasodilator response to $\mathrm{Up}_{4} \mathrm{~A}$ was maintained in metabolic derangement. However, the contribution of purinergic receptor subtypes and endotheliumderived factors was markedly altered.

\section{Materials and methods}

\section{Animals}

Diabetes was induced in 10 female swine (2-3 months old, $25.1 \pm 1.2 \mathrm{~kg}$ ) with intravenous injections of streptozotocin (50 mg/kg/day, Bioconnect, The Netherlands, AG-CN2-0046) for three days. This dose of streptozotocin resulted in a stable hyperglycemia, as evidenced by glucose levels of $19.5 \pm 1.4$ (week 1), $21.6 \pm 2.9$ (week 3), $18.8 \pm 2.0$ (week 18), and $18.7 \pm 2.1 \mathrm{mmol} / 1$ (week 20). One to two weeks after diabetes induction, a high-fat diet (25\% saturated fats and $1 \%$ cholesterol) was gradually introduced [3]. Swine were housed in metabolic cages with ad libitum access to food for $1 \mathrm{~h}$ per meal, twice daily for the entire 6-month study duration. The diabetic status was regularly monitored by measurement of glucose and ketone levels in urine and blood. At sacrifice, swine with metabolic derangement weighed $104 \pm 8 \mathrm{~kg}$. Five healthy female crossbred Yorkshire $\times$ Landrace swine, purchased from the same breeder two weeks prior to sacrifice and matched for age and weight to swine with metabolic derangement (8-9 months old, $119 \pm 5 \mathrm{~kg}$ ), served as a control group.

\section{Blood and tissue sampling}

At sacrifice, animals were sedated with an intramuscular injection of Zoletil (Tiletamine/Zolazepam; $5 \mathrm{mg} / \mathrm{kg}$ ) and Xylazine $(2.25 \mathrm{mg} / \mathrm{kg})$, anesthetized with pentobarbital $(20 \mathrm{mg} / \mathrm{kg} / \mathrm{h}$ i.v.) and artificially ventilated. Catheters were inserted for arterial blood sampling [24]. The collected blood samples were stored for later determination of lipids, glucose and insulin levels. Following thoracotomy, hearts were arrested and immediately excised and placed in cold, oxygenated Krebs bicarbonate buffer solution.

\section{Myograph studies}

Left ventricular apices from female swine with metabolic derangement $(n=10)$ and normal swine $(n=5)$ were collected at the time of sacrifice. Additional apices were collected from 8 hearts of healthy swine ( 3 female +5 unknown gender) obtained from a local slaughterhouse. When the vascular response to $\mathrm{Up}_{4} \mathrm{~A}$ (Biolog Life Science, Germany, U008) in the 8 female swine did not differ from the 5 swine of unknown gender from the slaughterhouse, data were pooled into a single control group (normal, $n=13$ ), otherwise only data from coronary small arteries of female swine were used.

Coronary small arteries (diameter $\sim 150 \mu \mathrm{m}$ ) were dissected out from the apex of 7 swine with metabolic derangement and 13 normal swine and stored overnight in cold, oxygenated Krebs bicarbonate solution of the following composition (mM): $\mathrm{NaCl} 118, \mathrm{KCl} 4.7, \mathrm{CaCl}_{2}$ 2.5, $\mathrm{MgSO}_{4}$ 1.2, $\mathrm{KH}_{2} \mathrm{PO}_{4}$ 
$1.2, \mathrm{NaHCO}_{3} 25$, and glucose $8.3 ; \mathrm{pH} 7.4[15,25]$. The next day, coronary arteries were cut into segments of $\sim 2 \mathrm{~mm}$ length and mounted in microvascular myographs (Danish Myo Technology) in separate $6 \mathrm{ml}$ organ baths containing Krebs bicarbonate solution aerated with $95 \% \mathrm{O}_{2} / 5 \% \mathrm{CO}_{2}$ and maintained at $37{ }^{\circ} \mathrm{C}$. Changes in contractile force were recorded with a Harvard isometric transducer. Following a 30-min stabilization period, the internal diameter was set at a tension equivalent to 0.9 times the estimated diameter at $100 \mathrm{mmHg}$ effective transmural pressure [15, 25]. At the end of the stabilization period, the vessels were exposed to $30 \mathrm{mM} \mathrm{KCl}$ twice to check the contractility. Endothelial integrity was verified by observing relaxation to $10 \mathrm{nM}$ substance $\mathrm{P}$ after preconstriction with $100 \mathrm{nM}$ of the stable thromboxane $\mathrm{A}_{2}$ analogue 9,11-dideoxy-11 $\alpha, 9 \alpha$-epoxymethanoprostaglandin F2 $\alpha$ (U46619). Then, vessels were subjected to $100 \mathrm{mM}$ $\mathrm{KCl}$ to determine the maximal vascular contraction. Thereafter, vessels were allowed to equilibrate in fresh Krebs solution for $30 \mathrm{~min}$ before initiating different experimental protocols [15, 25]. In experiments where the effect of an antagonist on the response to $\mathrm{Up}_{4} \mathrm{~A}$ was assessed, antagonists were added to the organ baths $30 \mathrm{~min}$ before preconstriction with U46619 and were present throughout the experiments. Only one protocol was executed per vessel segment, and, within one protocol, each vessel was obtained from a different animal.

\section{Experimental protocols}

The coronary small arteries from both normal swine and swine with metabolic derangement were subjected to increasing $\mathrm{Up}_{4} \mathrm{~A}$ concentrations $\left(10^{-9}-10^{-5} \mathrm{M}\right)$. Since no vasoconstrictor influence was observed in vessels from both normal swine and swine with metabolic derangement (data not shown), vessels were preconstricted with U46619 to study the vasodilator effect of $\mathrm{Up}_{4} \mathrm{~A}$ and the signaling pathways involved.

To investigate the involvement of purinergic receptors in $\mathrm{Up}_{4} \mathrm{~A}$-induced relaxation, preconstricted coronary small arteries from both normal swine and swine with metabolic derangement were exposed to increasing $\mathrm{Up}_{4} \mathrm{~A}$ concentrations $\left(10^{-9}\right.$ $10^{-5} \mathrm{M}$ ), in the absence and presence of the non-selective P1 receptor antagonist 8-phenyltheophylline (8PT, $10 \mu \mathrm{M}$, SigmaAldrich, The Netherlands, P2278), the non-selective P2 receptor antagonist pyridoxalphosphate-6-azophenyl-2',4'-disulfonic acid (PPADS, $10 \mu \mathrm{M}$, Sigma-Aldrich, The Netherlands, $\mathrm{P} 178$ ), and combined P1 and P2 receptor blockade [15, 23]. To assess the role of purinergic receptor subtypes, vessels were tested in the absence and presence of adenosine $\mathrm{A}_{2 \mathrm{~A}}$ receptor antagonist SCH58261 (100 nM, Sigma-Aldrich, The Netherlands, S4568), P2X 1 receptor antagonist MRS2159 (30 $\mu \mathrm{M}$, Sigma-Aldrich, The Netherlands, M7684) [15, 23, 26], $\mathrm{P}_{2} \mathrm{X}_{7}$ receptor antagonist A438079 $(10 \mu \mathrm{M}$, Sigma-Aldrich, The Netherlands, A9736) [27], $\mathrm{P} 2 \mathrm{Y}_{1}$ receptor antagonist
MRS2179 (1 $\mu \mathrm{M}$, Sigma-Aldrich, The Netherlands, M3808), or $\mathrm{P}_{2} \mathrm{Y}_{6}$ antagonist MRS2578 $(10 \mu \mathrm{M}$, Sigma-Aldrich, The Netherlands, M0319) [15, 23]. Although the purinergic receptor blockers, in the concentrations employed in the present study, predominantly block the receptor subtypes they were designed for, it cannot be entirely excluded that other purinergic receptors were, to some extent, also affected. Careful evaluation of the selectivity profiles is therefore necessary to properly interpret the results in the present study. MRS2159 has been shown to block, in addition to $\mathrm{P} 2 \mathrm{X}_{1}$ receptors, $\mathrm{P} 2 \mathrm{X}_{2}, \mathrm{P} 2 \mathrm{X}_{2 / 3}$, and $\mathrm{P} 2 \mathrm{Y}_{1}$ receptors in $1321 \mathrm{~N} 1$ cells [27] and $\mathrm{P} 2 \mathrm{X}_{7}$ receptors in $1321 \mathrm{~N} 1$ cells and erythrocytes [27, 28]. Moreover, while A438079, at concentrations up to $100 \mu \mathrm{M}$, has been shown to be selective for $\mathrm{P} 2 \mathrm{X}_{7}$ receptors as compared to $\mathrm{P} 2 \mathrm{X}_{1}, \mathrm{P} 2 \mathrm{X}_{2 \mathrm{a}}, \mathrm{P} 2 \mathrm{X}_{2 / 3}, \mathrm{P} 2 \mathrm{X}_{4}$, $\mathrm{P}_{2} \mathrm{Y}_{1}$, and $\mathrm{P} 2 \mathrm{Y}_{2}$ receptors in 1321N1 cells [29], other purinergic receptor subtypes were not tested. MRS2179 was shown to inhibit neither the response to UTP at the human $\mathrm{P}_{2} \mathrm{Y}_{2}$ and $\mathrm{P}_{2} \mathrm{Y}_{4}$ receptors nor the response to UDP at the $\mathrm{P} 2 \mathrm{Y}_{6}$ receptor, and it was found to be 11-fold and 130-fold more selective for $\mathrm{P} 2 \mathrm{Y}_{1}$ receptors than for $\mathrm{P} 2 \mathrm{X}_{1}$ and $\mathrm{P} 2 \mathrm{X}_{3}$ receptors, respectively, and to be inactive at rat $\mathrm{P} 2 \mathrm{X}_{2}$ and $\mathrm{P} 2 \mathrm{X}_{4}$ receptors in Xenopus oocytes [30]. MRS2578, at concentrations up to $10 \mu \mathrm{M}$, did not affect $\mathrm{P} 2 \mathrm{Y}_{1}, \mathrm{P}_{2} \mathrm{Y}_{2}, \mathrm{P}_{2} \mathrm{Y}_{4}$, and $\mathrm{P}_{2} \mathrm{Y}_{11}$ receptor-mediated responses in 1321N1 cells [31]. Finally, SCH58261 was shown to be 581-fold more selective for $\mathrm{A}_{2 \mathrm{~A}}$ than $\mathrm{A}_{2 \mathrm{~B}}$ receptors [32].

A subset of coronary small arteries was de-endothelialized, preconstricted with $100 \mathrm{nM} \mathrm{U} 46619$, and exposed to increasing $\mathrm{Up}_{4} \mathrm{~A}$ concentrations $\left(10^{-9}-10^{-5} \mathrm{M}\right)$. Other endotheliumintact coronary small arteries from both normal swine and swine with metabolic derangement were preconstricted with $\mathrm{U} 46619$ and exposed to increasing $\mathrm{Up}_{4} \mathrm{~A}$ concentrations in the absence and presence of the nitric oxide synthase (NOS) inhibitor LNAME $(100 \mu \mathrm{M}$, Sigma-Aldrich, The Netherlands, N5751), LNAME in combination with the cyclooxygenase inhibitor indomethacin $(10 \mu \mathrm{M}$, Sigma-Aldrich, The Netherlands, 17378) [15], or LNAME + indomethacin + the cytochrome $\mathrm{P}_{450} 2 \mathrm{C} 9$ (CYP 2C9) inhibitor sulfaphenazole (10 $\mu \mathrm{M}$, Sigma-Aldrich, The Netherlands, S0758) [15, 23]. Finally, the effect of thromboxane synthase inhibitor ozagrel (10 $\mu \mathrm{M}$, Sigma-Aldrich, The Netherlands, O1385) on the coronary vasodilator response to $\mathrm{Up}_{4} \mathrm{~A}$ was studied in the absence and presence of LNAME.

MRS2578 and indomethacin were firstly dissolved in DMSO and further diluted in distilled water. Sulfaphenazole was dissolved in ethanol and further diluted in distilled water. Other drugs were dissolved in distilled water. PPADS and MRS2159 were protected from light.

\section{Quantitative real-time PCR analysis}

Following dissection, endothelium-intact coronary small arteries were snap-frozen in liquid nitrogen to be used for detection of $\mathrm{A}_{2 \mathrm{~A}}, \mathrm{P} 2 \mathrm{X}_{1}, \mathrm{P} 2 \mathrm{X}_{4}, \mathrm{P} 2 \mathrm{X}_{7}, \mathrm{P} 2 \mathrm{Y}_{1}, \mathrm{P}_{2} \mathrm{Y}_{2}, \mathrm{P} 2 \mathrm{Y}_{4}$, and 
$\mathrm{P}_{2} \mathrm{Y}_{6}$ receptors mRNA. In addition, the expression of endothelial NOS (eNOS) was measured [33]. Total RNA was extracted from 5 to 7 frozen samples per group using a Qiagen RNA kit. cDNA was synthesized from $100 \mathrm{ng}$ of total RNA with iScript Reverse Transcriptase (Bio-Rad). Quantitative real-time PCR (MyIQ, Bio-Rad) was performed with SYBR Green (Bio-Rad) [15]. Target gene mRNA levels were expressed relative to the housekeeping gene glyceraldehyde-3-phosphate dehydrogenase (GAPDH) as an endogenous control [34]. Primer sequences are shown in Table 1.

\section{Data analysis and statistics}

Data are presented as mean \pm SEM. Statistical analysis of plasma lipids, glucose and insulin was performed using an unpaired two-tailed $t$ test. Vascular relaxation responses to $\mathrm{Up}_{4} \mathrm{~A}$ were expressed as percentage of contraction to $\mathrm{U} 46619$ [15]. The effects of drug treatment on $\mathrm{Up}_{4} \mathrm{~A}$ responses were analyzed using two-way ANOVA for repeated measures. Statistical significance was accepted when $P<0.05$ (two-tailed).

\section{Results}

\section{Characteristics of diabetes and metabolic derangement}

Metabolic derangement was present six months after induction of diabetes with streptozotocin and start of a high-fat diet. Plasma levels of glucose, total cholesterol, high density lipoprotein (HDL), low density lipoprotein (LDL), and triglycerides in swine with metabolic derangement were significantly elevated as compared to normal swine, while insulin levels were similar (Table 2). Fatty streaks were observed in the proximal coronary arteries, but plaque burden never amounted more than $10 \%$ of the vascular lumen; fatty streaks were not observed in the coronary microvessels.

\section{Vasoactive influence of $U \mathbf{p}_{4} A$ on coronary vasculature in swine with metabolic derangement}

$\mathrm{Up}_{4} \mathrm{~A}$ failed to elicit any vasoconstrictor response in coronary small arteries from either normal swine or swine with metabolic derangement (data not shown). Following preconstriction with $\mathrm{U} 46619, \mathrm{Up}_{4} \mathrm{~A}$ produced concentrationdependent relaxation up to $100 \%$, which was virtually identical between the two groups (Fig. 1). In contrast, bradykinin $\left(10^{-10}-10^{-6} \mathrm{M}\right)$-induced endothelium-dependent relaxation in coronary small arteries was impaired in swine with metabolic derangement $\left(-\log \mathrm{EC}_{50} 8.61 \pm 0.12\right.$ in normal $(n=6)$ vs $7.89 \pm 0.19$ in metabolic derangement $(n=5) ; P<0.05)$.

\section{Effect of metabolic derangement on function and expression of purinergic receptor subtypes}

Non-selective P1 receptor blockade with 8PT and, to a lesser extent, non-selective $\mathrm{P} 2$ receptor blockade with PPADS attenuated the coronary vasodilator response to $\mathrm{Up}_{4} \mathrm{~A}$ (Fig. 2). These responses were however not different between the two groups. In contrast, while the effect of combined administration of 8PT and PPADS was similar to the effect of 8PT alone in normal swine (Fig. 2a), the effect of 8PT and PPADS was significantly greater than the effect of 8PT alone in swine with metabolic derangement with unmasking of a mild vasoconstrictor response to $\mathrm{Up}_{4} \mathrm{~A}$ (Fig. 2b).

$\mathrm{A}_{2 \mathrm{~A}}$ receptor blockade resulted in attenuation of the response to $\mathrm{Up}_{4} \mathrm{~A}$ that was comparable with the attenuation by 8PT and was not different between coronary small arteries from normal swine and swine with metabolic derangement (Fig. 3a, f), despite slightly lower $A_{2 A}$ mRNA expression

Table 1 Primer information

\begin{tabular}{|c|c|c|c|}
\hline \multirow[t]{2}{*}{ Genes } & \multicolumn{2}{|l|}{ Sequence } & \multirow[t]{2}{*}{ Size } \\
\hline & Sense & Antisense & \\
\hline $\mathrm{A}_{2 \mathrm{~A}}$ & 5'-ATGTTGGGCTGGAATAGCTG-3' & 5'-CACGGAGTTGGTGTGAGAGA-3' & $426 \mathrm{bp}$ \\
\hline $\mathrm{P} \mathrm{X}_{1}$ & 5'-TTGAACCCCATTTCTTCCTG-3' & 5'-AGTGCACCACACATCTGCTC-3' & $248 \mathrm{bp}$ \\
\hline $\mathrm{P} 2 \mathrm{X}_{4}$ & 5'-TGTCCCCAGGCTACAATTTC-3' & 5'-GGCAGCTTTTTCTCCCTTCT-3' & $373 \mathrm{bp}$ \\
\hline $\mathrm{P} 2 \mathrm{X}_{7}$ & 5'-CTTTTGCACCTTGAGCTTCC-3' & 5'-TCCATGCTAAGGGATTCTGG-3' & $152 \mathrm{bp}$ \\
\hline $\mathrm{P}_{2} \mathrm{Y}_{1}$ & 5'-TTCCTGACTTGCATCAGTGC-3' & 5'-CAGTGCCCGAGTAGAAGAGG-3' & $157 \mathrm{bp}$ \\
\hline $\mathrm{P} \mathrm{Y}_{2}$ & 5'-GTGGCCTACAGCTTGGTCAT-3' & 5'-GCGTGCGGAAGGAGTAGTAG-3' & $235 \mathrm{bp}$ \\
\hline $\mathrm{P} \mathrm{Y}_{4}$ & 5'-GACTGCCGGTTTAATGAGGA-3' & 5'-AGGAAAAGGACGCTGCAGTA-3' & $302 \mathrm{bp}$ \\
\hline $\mathrm{P} \mathrm{Y}_{6}$ & 5'-CTGCTCTTGCCACCTGTGTA-3' & 5'-AGGTTGGCGTAGAACAGGAA-3' & $251 \mathrm{bp}$ \\
\hline eNOS & 5'-СТCTCCTGTTGGCCTGACCA-3' & 5'-CCGGTTACTCAGACCCAAGG-3' & $151 \mathrm{bp}$ \\
\hline GAPDH & 5'-TCGGAGTGAACGGATTTG-3' & 5'-CCTGGAAGATGGTGATGG-3' & $219 \mathrm{bp}$ \\
\hline
\end{tabular}


Table 2 Plasma and lipid parameters of variables

\begin{tabular}{lcc}
\hline & Normal $(n=5)$ & Metabolic derangement $(n=10)$ \\
\hline Insulin $(\mathrm{pmol} / \mathrm{l})$ & $2.50 \pm 0.48$ & $3.42 \pm 0.92$ \\
Glucose $(\mathrm{mmol} / \mathrm{l})$ & $5.32 \pm 0.77$ & $16.58 \pm 1.07^{*}$ \\
Cholesterol $(\mathrm{mmol} / \mathrm{l})$ & $2.22 \pm 0.34$ & $16.45 \pm 2.10^{*}$ \\
HDL $(\mathrm{mmol} / \mathrm{l})$ & $0.88 \pm 0.11$ & $3.74 \pm 0.59^{*}$ \\
LDL (mmol/l) & $1.38 \pm 0.27$ & $14.35 \pm 1.98^{*}$ \\
Triglycerides (mmol/l) & $0.15 \pm 0.04$ & $0.63 \pm 0.11^{*}$ \\
\hline
\end{tabular}

$H D L$ high density lipoprotein, $L D L$, low density lipoprotein. Values are mean $\pm \mathrm{SEM}$; $* P<0.05$ vs. normal levels in coronary small arteries of metabolic derangement (Fig. 4). P2X $\mathrm{X}_{1}$ receptor blockade with MRS2159 attenuated $\mathrm{Up}_{4} \mathrm{~A}$-induced relaxation to a similar extent in coronary small arteries from normal swine and swine with metabolic derangement (Fig. 3b, g), which was consistent with the unaltered $\mathrm{P} 2 \mathrm{X}_{1}$ mRNA expression between the two groups (Fig. 4). $\mathrm{P}_{2} \mathrm{X}_{7}$ receptor blockade with A438079 attenuated the vasodilator response to $\mathrm{Up}_{4} \mathrm{~A}$ in coronary small arteries from normal swine (Fig. 3c) but not from swine with metabolic derangement (Fig. 3h), which was consistent with the reduced coronary $\mathrm{P}_{2} \mathrm{X}_{7}$ mRNA expression in swine with metabolic derangement (Fig. 4). In contrast, $\mathrm{P}_{2} \mathrm{Y}_{1}$ blockade with MRS2179 attenuated $\mathrm{Up}_{4} \mathrm{~A}$-induced relaxation only in coronary small arteries from swine with metabolic derangement (Fig. 3i) but not from normal swine (Fig. 3d) despite the unaltered mRNA expression of $\mathrm{P}_{2} \mathrm{Y}_{1}$ receptors (Fig. 4). The attenuation by $\mathrm{P}_{2} \mathrm{Y}_{6}$ blockade with MRS2578 of $\mathrm{Up}_{4} \mathrm{~A}$-induced vasorelaxation and the $\mathrm{P}_{2} \mathrm{Y}_{6}$ mRNA expression were comparable between coronary small arteries of normal swine and swine with metabolic derangement (Figs. 3e, j and 4).

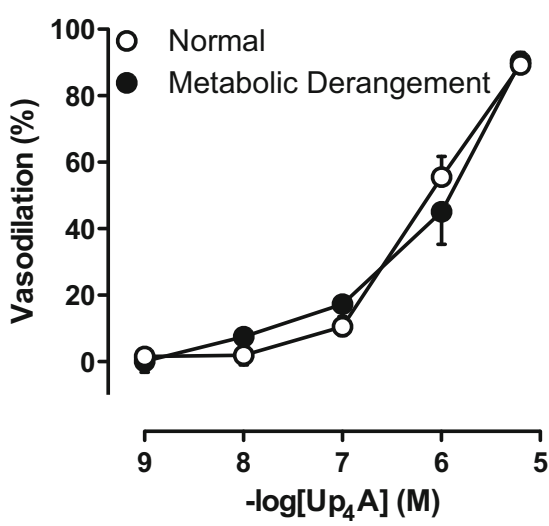

Fig. 1 Vasodilator effects of $\mathrm{Up}_{4} \mathrm{~A}$. Shown are concentration responses to $\mathrm{Up}_{4} \mathrm{~A}\left(10^{-9}-10^{-5} \mathrm{M}\right)$ in coronary small arteries preconstricted with U46619 $(100 \mathrm{nM})$ from normal swine $(n=13)$ and swine with metabolic derangement $(n=10)$. Values are mean \pm SEM

\section{Role of endothelium in $\mathrm{Up}_{4} \mathrm{~A}$-induced coronary relaxation}

Endothelial denudation, as confirmed by the absence of a vasodilator response to substance $\mathrm{P}$ (data not shown), attenuated the vasodilator response to $\mathrm{Up}_{4} \mathrm{~A}$ in coronary small arteries from normal swine (Fig. 5a) but not from swine with metabolic derangement (Fig. 5d). Similarly, eNOS inhibition with LNAME attenuated the response to $\mathrm{Up}_{4} \mathrm{~A}$ in vessels from normal swine (Fig. 5a) but not from swine with metabolic derangement (Fig. 5d), which was consistent with the reduced eNOS expression in swine with metabolic derangement, from $0.52 \pm 0.14$ in normal to $0.19 \pm 0.03$ in metabolic derangement $(P<0.05)$. Additional COX-inhibition with indomethacin had no effect in coronary small arteries from either normal swine (Fig. 5b) or swine with metabolic derangement (Fig. 5e). In the presence of combined eNOS and COX blockade, inhibition of CYP 2C9 with sulfaphenazole enhanced the relaxation to $\mathrm{Up}_{4} \mathrm{~A}$ in coronary small arteries from normal swine, (Fig. 5c), whereas in vessels from swine with metabolic derangement, sulfaphenazole attenuated the vasorelaxation to $\mathrm{Up}_{4} \mathrm{~A}$ (Fig. 5f). These findings suggest that CYP $2 \mathrm{C} 9$ switches from the production of vasoconstrictor metabolites in normal swine to vasodilator metabolites in swine with metabolic derangement.

The thromboxane synthase inhibitor ozagrel had no effect on $\mathrm{Up}_{4} \mathrm{~A}$-induced relaxation in coronary small arteries from either normal swine (Fig. 6a) or swine with metabolic derangement (Fig. 6c). However, while in normal swine, in the presence of LNAME, ozagrel failed to significantly affect $\mathrm{Up}_{4} \mathrm{~A}$-induced relaxation of coronary small arteries (Fig. 6b, $P=0.17$ ), ozagrel significantly enhanced the vasodilator response to $\mathrm{Up}_{4} \mathrm{~A}$ in coronary small arteries from swine with metabolic derangement (Fig. 6d).

\section{Discussion}

The present study is the first to investigate the coronary vascular effects of the dinucleotide $\mathrm{Up}_{4} \mathrm{~A}$ in a large animal model of metabolic derangement. The main findings were that (1) 


\section{Normal}

\section{A}

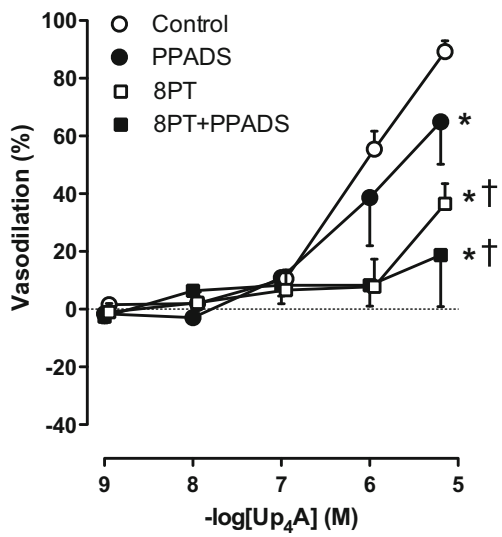

Fig. 2 Effects of non-selective purinergic receptor blockade on $U_{4} \mathrm{~A}$ induced relaxation. Shown are concentration responses to $\mathrm{Up}_{4} \mathrm{~A}\left(10^{-9}\right.$ $10^{-5} \mathrm{M}$ ) in porcine coronary small arteries in the control vessels (normal, $n=13$; metabolic derangement, $n=7$ ) and in the presence of $10 \mu \mathrm{M}$ nonselective $\mathrm{P} 1$ receptor antagonist $8 \mathrm{PT}$ (normal, $n=5$; metabolic derangement, $n=6$ ), in the presenc e of $10 \mu \mathrm{M}$ non-selective $\mathrm{P} 2$ receptor

$\mathrm{Up}_{4} \mathrm{~A}$-induced relaxation was not altered in coronary small arteries isolated from swine with metabolic derangement as compared to normal swine, despite the presence of endothelial dysfunction; (2) combined P1 and P2 receptor blockade had an additive effect in swine with metabolic derangement but not in normal swine; (3) there was a shift in involvement of purinergic receptors from $\mathrm{P} 2 \mathrm{X}_{7}$ receptors in normal swine to

\section{Metabolic Derangement}

B

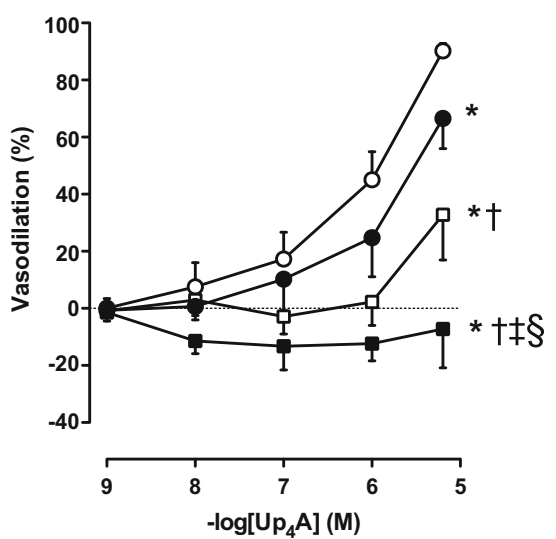

antagonist PPADS (normal, $n=5$; metabolic derangement, $n=7$ ) as well as in the presence of combined 8PT and PPADS (normal, $n=6$; metabolic derangement, $n=4)$. Values are mean \pm SEM. $* P<0.05$ vs. Control; $\dagger P<0.05$ vs. PPADS; $₫ P<0.05$ vs. $8 \mathrm{PT} ; \S P<0.05$ effect of $8 \mathrm{PT}+$ PPADS in metabolic derangement differs from that in normal

$\mathrm{P}_{2} \mathrm{Y}_{1}$ receptors in swine with metabolic derangement; (4) endothelial denudation as well as eNOS inhibition attenuated the response to $\mathrm{Up}_{4} \mathrm{~A}$ in normal swine but not in swine with metabolic derangement, and eNOS inhibition unmasked thromboxane production in swine with metabolic derangement, but not normal swine, in response to $\mathrm{Up}_{4} \mathrm{~A}$; and (5) CYP $2 \mathrm{C} 9$ metabolites exerted a vasoconstrictor influence in response
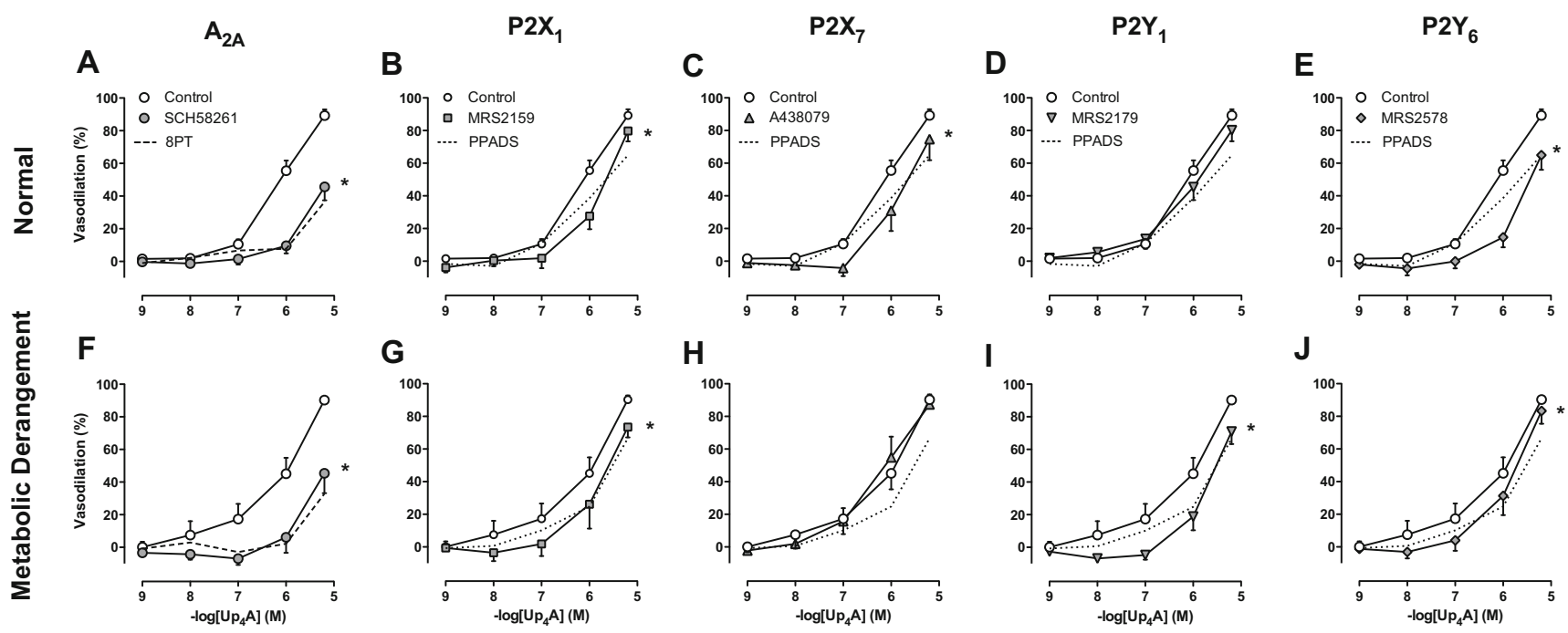

$\mathbf{J}$

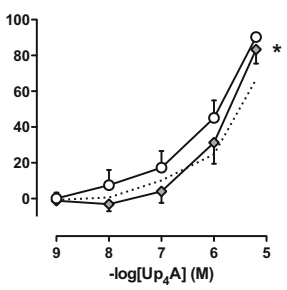

Fig. 3 Involvement of purinergic receptor subtypes in $\mathrm{Up}_{4} \mathrm{~A}$-induced relaxation. Shown are concentration responses to $\mathrm{Up}_{4} \mathrm{~A}\left(10^{-9}-10^{-5} \mathrm{M}\right)$ in porcine coronary small arteries in control vessels (normal, $n=13$; metabolic derangement, $n=7$ ) and in the presence of $100 \mathrm{nM} \mathrm{A} 2 \mathrm{~A}$ receptor antagonist SCH58261 (normal $(n=8$, panel a); metabolic derangement $(n=7$, panel $\mathbf{f})$ ); in the presence of $30 \mu \mathrm{M} \mathrm{P} 2 \mathrm{X}_{1}$ receptor antagonist MRS2159 (normal ( $n=6$, panel b); metabolic derangement $(n=7$, panel $\mathbf{g})$ ); in the presence of $10 \mu \mathrm{M} \mathrm{P} 2 \mathrm{X}_{7}$ receptor antagonist A438079 (normal ( $n=7$, panel c); metabolic derangement $(n=6$, panel

h)); in the presence of $1 \mu \mathrm{M} \mathrm{P} 2 \mathrm{Y}_{1}$ receptor antagonist MRS2179 (normal $(n=9$, panel d); metabolic derangement $(n=7$, panel $\mathbf{i})$ ); and in the presence of $10 \mu \mathrm{M} \mathrm{P} 2 \mathrm{Y}_{6}$ receptor antagonist MRS2578 (normal $(n=6$, panel e); metabolic derangement $(n=6$, panel $\mathbf{j}))$. For the sake of comparison, non-selective P1 blockade with 8PT (normal, $n=10$; metabolic derangement, $n=6$ ) is shown as dotted line in panels a and $\mathbf{f}$, while non-selective P2 blockade with PPADS (normal, $n=5$; metabolic derangement, $n=7$ ) is shown as dotted line in panels $\mathbf{b}, \mathbf{c}, \mathbf{d}, \mathbf{e}, \mathbf{g}, \mathbf{h}, \mathbf{i}$, and $\mathbf{j}$. Values are mean \pm SEM. $* P<0.05$ vs. control 


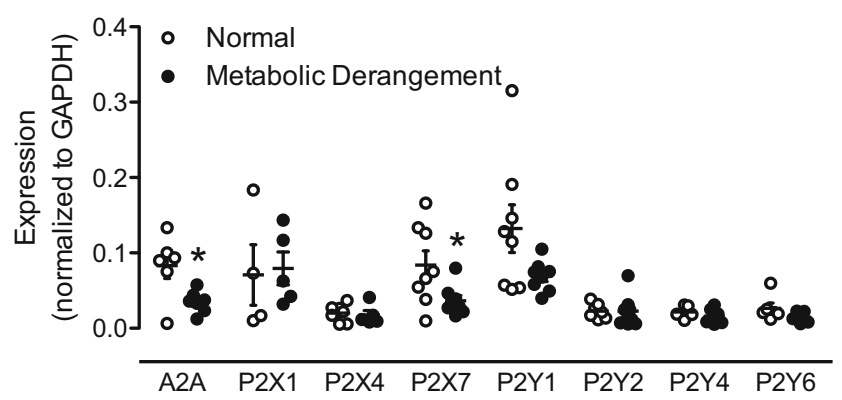

Fig. 4 Expression profile of various purinergic receptor subtypes in normal and metabolic derangement. mRNA levels of each gene were normalized to that of housekeeping gene GAPDH. Data in the normal group are identical to those published in [23] but were performed in parallel to the experiments in the vessels obtained from animals with metabolic derangement. Values are mean \pm SEM. $* P<0.05$ vs. normal

to $\mathrm{Up}_{4} \mathrm{~A}$ in normal swine but exerted a vasodilator influence on the $\mathrm{Up}_{4} \mathrm{~A}$ responses in swine with metabolic derangement. The implications of these findings will be discussed below.

The dinucleotide $\mathrm{Up}_{4} \mathrm{~A}$ was initially identified as a novel endothelium-derived vasoconstrictor [6]. Subsequent studies demonstrated that $\mathrm{Up}_{4} \mathrm{~A}$ induces vascular contraction in most vascular beds, including mouse renal arterioles [35], mouse aortas [11, 36, 37], rat aortas [12], rat mesenteric arteries [9], rat pulmonary arteries [7], and rat renal arteries [6], particularly in the presence of diabetes [13]. In addition to its vasoconstrictor effects in most vascular beds under basal tone, $\mathrm{Up}_{4} \mathrm{~A}$ can act as a vasodilator when vascular tone is elevated in the rat aortas and rat perfused kidney $[12,38]$. In contrast, we previously found that $\mathrm{Up}_{4} \mathrm{~A}$ is purely a vasodilator in the healthy porcine coronary microcirculation, without any vasoconstrictor activity [15]. We also recently found that this vasodilator response to $\mathrm{Up}_{4} \mathrm{~A}$ is reduced after myocardial infarction in coronary microvessels supplying the remote myocardium [23]. Surprisingly, we did not observe any blunting of the coronary vasodilator response to $\mathrm{Up}_{4} \mathrm{~A}$ in swine with metabolic derangement as compared to normal swine in the present study (Fig. 1), despite evidence of endothelial dysfunction as indicated by the blunted endothelium-dependent relaxation to bradykinin both at 2 months in our previous study [3] as well as 6 months of metabolic derangement in the present

\section{Endothelium - NOS}

A
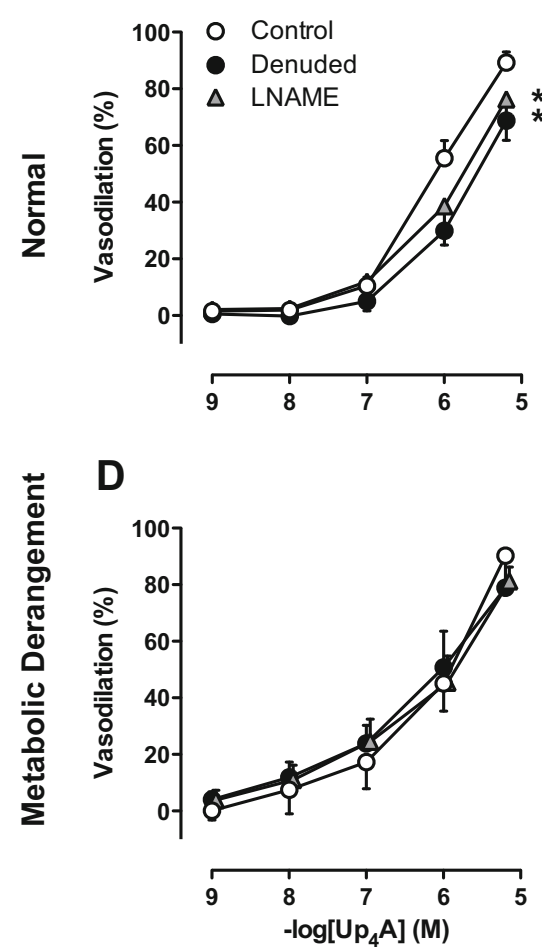

cox

B

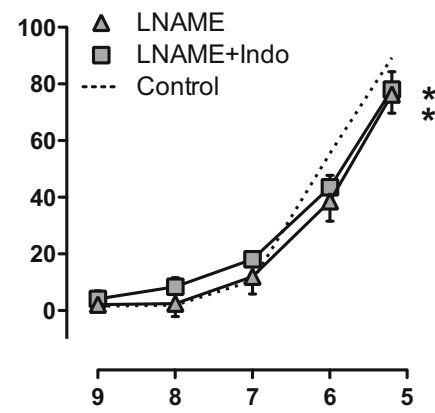

E

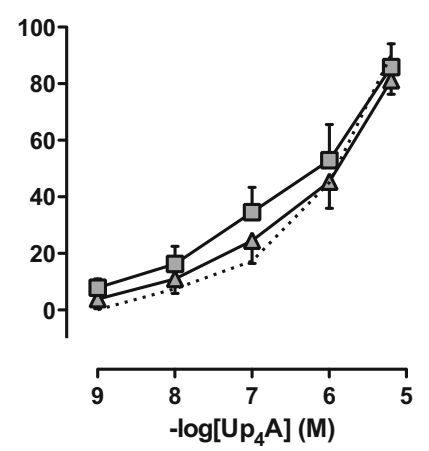

\section{CYP 2 C9}

\section{C}

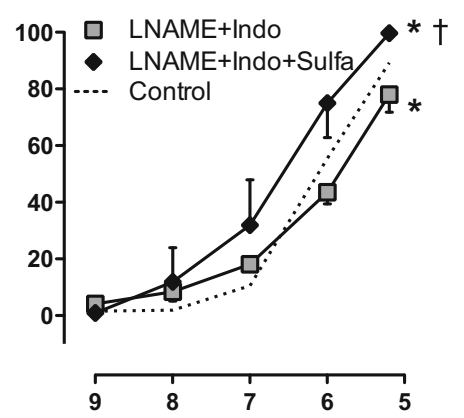

$\mathbf{F}$

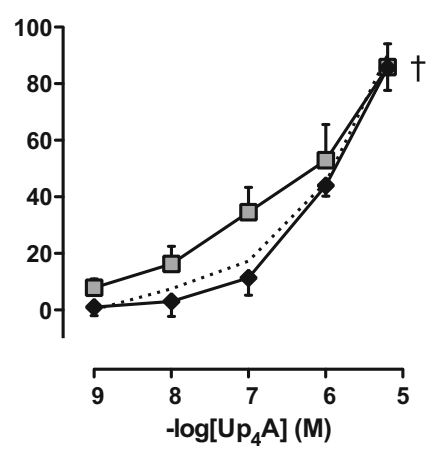

Fig. 5 Involvement of the endothelium and endothelium-derived vasoactive factors in $\mathrm{Up}_{4} \mathrm{~A}$-induced relaxation. Shown are concentration responses to $\mathrm{Up}_{4} \mathrm{~A}\left(10^{-9}-10^{-5} \mathrm{M}\right)$ in porcine coronary small arteries in the absence and presence of endothelium (normal ( $n=13$ with endothelium; $n=7$ without endothelium, panel a); metabolic derangement ( $n=7$ with endothelium; $n=6$ without endothelium, panel d)); in the presence of $100 \mu \mathrm{M}$ of the NOS inhibitor LNAME (normal $(n=8$, panel a); metabolic derangement $(n=7$, panel $\mathbf{d})$ ); in the presence of combined
LNAME and $10 \mu \mathrm{M}$ of the COX inhibitor indomethacin (indo, normal $(n=7$, panel b); metabolic derangement $(n=7$, panel $\mathbf{e})$ ); and in the presence of combined LNAME, indo, and $10 \mu \mathrm{M}$ CYP 2C9 inhibitor sulfaphenazole (sulfa, normal $(n=4$, panel c); metabolic derangement $(n=4$, panel $\mathbf{f})$ ). For the sake of comparison, the effect of $\mathrm{Up}_{4} \mathrm{~A}$ in the absence of any blockers is shown as dotted line in panels $\mathbf{b}, \mathbf{c}, \mathbf{e}$, and $\mathbf{f}$. Values are mean \pm SEM. $* P<0.05$ vs. control; $\uparrow P<0.05$ effect of sulfa after LNAME + indo 
Fig. 6 Involvement of thromboxane in $\mathrm{Up}_{4} \mathrm{~A}$-induced relaxation. Shown are concentration responses to $\mathrm{Up}_{4} \mathrm{~A}$ $\left(10^{-9}-10^{-5} \mathrm{M}\right)$ in the presence and absence of $10 \mu \mathrm{M}$ of the thromboxane synthase inhibitor ozagrel in porcine coronary small arteries (normal $(n=5$, panel a); metabolic derangement $(n=4$, panel c)), as well as in the presence of $100 \mu \mathrm{M}$ of the NOS inhibitor LNAME (normal $(n=6$, panel b); metabolic derangement $(n=7$, panel d $))$. Values are mean \pm SEM. $* P<0.05$ effect of ozagrel vs. corresponding control
A

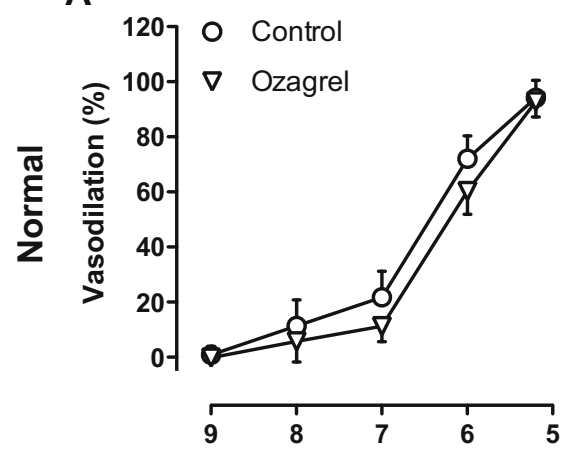

B
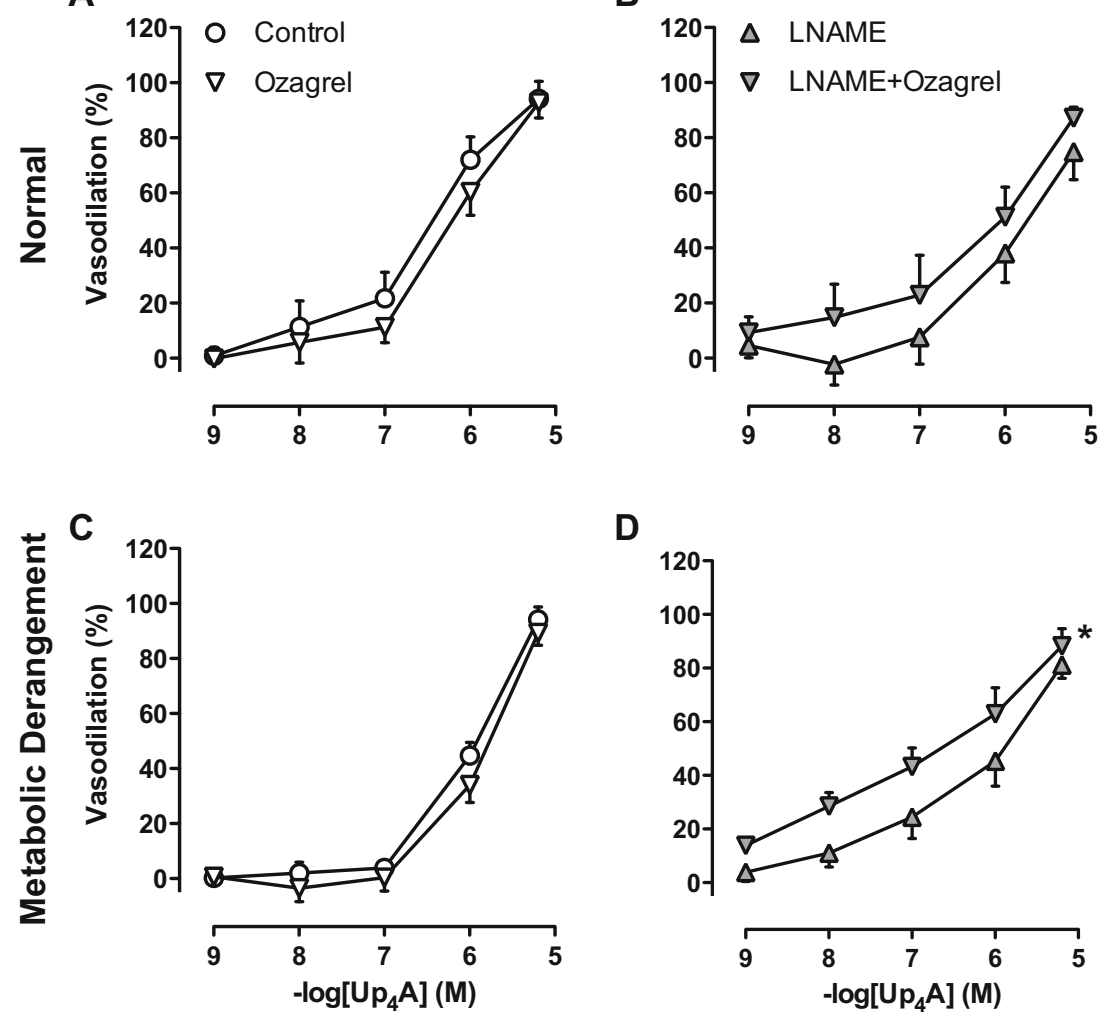

D

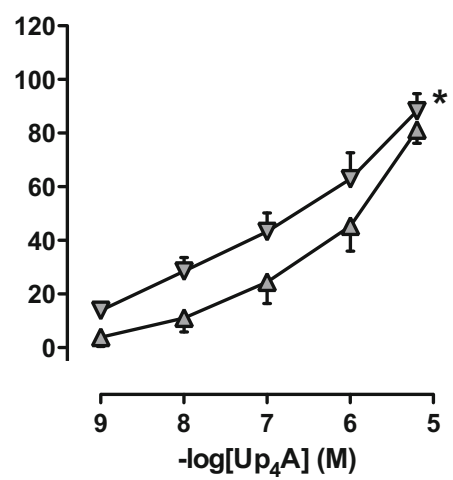

study. However, we did observe marked changes in the contribution of various purinergic receptor and endothelial mediators to the relaxation produced by $\mathrm{Up}_{4} \mathrm{~A}$.

In coronary small arteries from healthy swine, the vasodilator effect of $\mathrm{Up}_{4} \mathrm{~A}$ is principally mediated through $\mathrm{P} 1$ receptors, although the $\mathrm{P} 2 \mathrm{X}_{1}$ and $\mathrm{P} 2 \mathrm{Y}_{1}$ receptors also contribute in vessels of approximately $150 \mu \mathrm{m}$ in diameter [23] but not in vessels of 250-300 $\mu \mathrm{m}$ [15]. In coronary small arteries from swine with metabolic derangement, expression of the $\mathrm{A}_{2 \mathrm{~A}}$ receptor was slightly reduced, but a major part of the vasodilator effect of $\mathrm{Up}_{4} \mathrm{~A}$ was still exerted through this purinergic P1 receptor subtype. The effect of combined P1 and $\mathrm{P} 2$ receptor blockade was markedly enhanced in the coronary small arteries from swine with metabolic derangement, even unmasking a modest vasoconstrictor effect in response to $\mathrm{Up}_{4} \mathrm{~A}$, suggesting that the $\mathrm{P} 2$ receptor subtypes involved in response to $\mathrm{Up}_{4} \mathrm{~A}$ may differ between the two groups. Indeed, we found that both the expression and contribution of $\mathrm{P}_{2} \mathrm{X}_{7}$ receptors to $\mathrm{Up}_{4} \mathrm{~A}$-induced relaxation were decreased. In contrast, the contribution of $\mathrm{P}_{2} \mathrm{Y}_{1}$ receptors was increased in coronary small arteries from swine with metabolic derangement, even though expression of the $\mathrm{P}_{2} \mathrm{Y}_{1}$ receptors was not altered. The apparent discrepancy between receptor expression and function is likely due to the fact that receptor mRNA does not equate to receptor function. In addition, expression was studied in whole vessels so that we cannot distinguish expression in endothelial cells from vascular smooth muscle cells. P2 receptors in the vasculature are present on endothelial cells as well as on vascular smooth muscle cells. Activation of $\mathrm{P} 2 \mathrm{X}_{1}$ receptors and, in some vascular beds, $\mathrm{P} 2 \mathrm{X}_{2}, \mathrm{P} 2 \mathrm{X}_{4}$ and $\mathrm{P} 2 \mathrm{Y}_{1}, \mathrm{P} 2 \mathrm{Y}_{2}$, and $\mathrm{P} 2 \mathrm{Y}_{6}$ receptors on smooth muscle cells, generally results in vasoconstriction, although vasodilation is sometimes also observed [39]. Activation of $\mathrm{P}_{2} \mathrm{Y}_{1}, \mathrm{P}_{2} \mathrm{Y}_{2}$ and possibly also $\mathrm{P} 2 \mathrm{Y}_{4}, \mathrm{P}_{2} \mathrm{Y}_{11}, \mathrm{P} 2 \mathrm{X}_{1}, \mathrm{P} 2 \mathrm{X}_{2}$, $\mathrm{P} 2 \mathrm{X}_{3}, \mathrm{P} 2 \mathrm{X}_{4}$, and $\mathrm{P} 2 \mathrm{X}_{7}$ receptors on endothelial cells leads to the production of nitric oxide (NO) and subsequent vasodilation $[39,40]$. It is therefore possible that a shift in expression of the $\mathrm{P}_{2} \mathrm{Y}_{1}$ receptors from vascular smooth muscle to endothelium may have resulted in an increased contribution of these receptors to the vasodilator effect of $\mathrm{Up}_{4} \mathrm{~A}$. Interestingly, with age, a shift in $\mathrm{P}_{2} \mathrm{Y}_{1}$ receptors from endothelial cells to vascular smooth muscle cells was observed in the rat cerebral vasculature [41]. Consistent with these findings, we observed an attenuation of $\mathrm{Up}_{4} \mathrm{~A}$-induced vasorelaxation by $\mathrm{P}_{2} \mathrm{Y}_{1}$-receptor blockade in our previous study in healthy swine of approximately 4 months of age [23] but not in the present study in healthy swine of approximately 9 months of age. These findings also suggest that metabolic derangement may have prevented this age-dependent shift from endothelial to smooth muscle cell expression of $\mathrm{P}_{2} \mathrm{Y}_{1}$. Future studies are needed to investigate the metabolic disorder-induced changes in purinergic receptor subtype distribution between coronary endothelial and vascular smooth muscle cells in more detail. 
Metabolic derangement is accompanied by microvascular dysfunction and a shift in the balance between endotheliumderived vasodilators and vasoconstrictors $[4,5]$. In the present study, endothelial denudation blunted $\mathrm{Up}_{4} \mathrm{~A}$-induced relaxation in coronary small arteries from normal swine but not swine with metabolic derangement. This effect of endothelial denudation was similar to the effect of eNOS inhibition with LNAME, indicating a reduced involvement of NO in the vasodilator response to $\mathrm{Up}_{4} \mathrm{~A}$ in metabolic derangement. Reduced eNOS activity, which is a hallmark of coronary endothelial dysfunction in humans with metabolic derangement [42], was also observed in our previous study in coronary small arteries [3] and is consistent with the reduced eNOS expression in swine with metabolic derangement observed in the present study.

Endothelial dysfunction often results in a shift in production of endothelium-derived vasodilators, e.g., from NO to prostanoids and EDHF [43], and an increase in endotheliumderived vasoconstrictors such as thromboxane $[44,45]$. In the present study, we found that inhibition of COX had no effect in coronary small arteries from either normal swine or swine with metabolic derangement while the thromboxane synthase inhibitor ozagrel significantly enhanced the vasodilator response to $\mathrm{Up}_{4} \mathrm{~A}$ in the presence of eNOS inhibition in swine with metabolic derangement but not in normal swine, consistent with thromboxane production in response to $\mathrm{Up}_{4} \mathrm{~A}$. However, although NO-production was reduced in the coronary microvasculature of swine with metabolic derangement, there was no effect of thromboxane synthase inhibition in coronary small arteries with active eNOS, suggesting that even in metabolic derangement, NO suppresses the production of thromboxane. An increased contribution of thromboxane to vascular contraction in response to $\mathrm{Up}_{4} \mathrm{~A}$ was also recently shown in renal arteries from type 2 diabetic rats, although in that study the increased contribution of thromboxane appeared to be due to an increased sensitivity rather than an increased production of thromboxane [13]. However, in the present study, constriction to the stable thromboxane mimetic U46619 was not different between normal swine and swine with metabolic derangement (data not shown), indicating that sensitivity to thromboxane was not altered. A potential mechanism that has been proposed to underlie the increased thromboxane production in metabolic derangement is that lowgrade inflammation results in eNOS uncoupling, which subsequently leads to the production of reactive nitrogen species such as peroxinitrite, that is capable of inactivating $\mathrm{PGI}_{2}$-synthase and cause a shift in production from prostacyclin to thromboxane $[44,45]$.

EDHF has been demonstrated to compensate for the loss of NO in metabolic disorder [46], and CYP 2C9 has been reported to generate EETs that can act as an EDHF in the coronary vasculature [47]. In addition to these vasodilator EETs, CYP $2 \mathrm{C} 9$ can also produce ROS [48], which act as vasoconstrictors in the porcine coronary vasculature [49]. Although we have previously shown in pre-adolescent swine that inhibition of CYP 2C9 alone [15], or in the presence of inhibition of eNOS/ $\mathrm{COX}$ (unpublished data), does not affect $\mathrm{Up}_{4} \mathrm{~A}$-induced relaxation, we found in the present study in adult swine that inhibition of CYP 2C9, in the presence of inhibition of eNOS and $\mathrm{COX}$, potentiated the vasodilator response to $\mathrm{Up}_{4} \mathrm{~A}$ in coronary small arteries from normal swine. These data are consistent with the observations that CYP 2C9 activity increases with age [50] but predominantly produces ROS in healthy porcine coronary small arteries [48]. In contrast, in coronary small arteries from swine with metabolic derangement, inhibition of CYP 2C9 in the presence of eNOS- and COXinhibition reduced the vasorelaxation in response to $\mathrm{Up}_{4} \mathrm{~A}$, suggesting that CYP 2C9 switches from the production of vasoconstrictor to vasodilator metabolites in metabolic derangement. Such production of vasodilator metabolites by CYP 2C9 is consistent with other studies showing that CYP $2 \mathrm{C} 9$ metabolites can act as an EDHF [47] and that EDHF(s) is able to compensate for the chronic loss of NO in coronary vasculature in metabolic derangement [46].

In conclusion, while the overall vasodilator response to $\mathrm{Up}_{4} \mathrm{~A}$ was maintained in coronary small arteries of swine with metabolic derangement, the purinergic receptor subtypes as well as the EDVFs mediating this response were markedly altered. These findings suggest the presence of compensatory mechanisms among signaling pathways in $\mathrm{Up}_{4} \mathrm{~A}$-mediated coronary vasomotor influences in the early phase of metabolic derangement. Future studies are warranted to investigate the effects of severe metabolic derangement on coronary responses to $\mathrm{Up}_{4} \mathrm{~A}$.

Acknowledgements This work was supported by the European Commission FP7-Health-2010 Grant MEDIA-261409, the Netherlands CardioVascular Research Initiative CVON-RECONNECT 2014-11 (to D.J. Duncker and D. Merkus), the China Scholarship Council 2009624027 and the Southwestern Medical University China Development Grant MEPSCKL201301 (to Z. Zhou), as well as the Academy of Finland 251272 (to I. Heinonen).

\section{Compliance with ethical standards}

Conflicts of interest Author 1 declares that he/she has no conflict of interest.

Author 2 declares that he/she has no conflict of interest.

Author 3 declares that he/she has no conflict of interest.

Author 4 declares that he/she has no conflict of interest.

Author 5 declares that he/she has no conflict of interest.

Author 6 declares that he/she has no conflict of interest.

Author 7 declares that he/she has no conflict of interest.

Author 8 declares that he/she has no conflict of interest.

Ethical approval The studies were performed in accordance with the NIH Guide for the Care and Use of Laboratory Animals (8th edition, National Research Council. Washington, DC: The National Academies 
Press, 2011) and were approved by the Animal Care Committee at the Erasmus University Medical Center.

Open Access This article is distributed under the terms of the Creative Commons Attribution 4.0 International License (http:// creativecommons.org/licenses/by/4.0/), which permits unrestricted use, distribution, and reproduction in any medium, provided you give appropriate credit to the original author(s) and the source, provide a link to the Creative Commons license, and indicate if changes were made.

\section{References}

1. Ng AC, Delgado V, Djaberi R, Schuijf JD, Boogers MJ, Auger D, Bertini M, de Roos A, van der Meer RW, Lamb HJ, Bax JJ (2011) Multimodality imaging in diabetic heart disease. Curr Probl Cardiol 36(1):9-47. doi:10.1016/j.cpcardiol.2010.10.001

2. Paulus WJ, Tschope C (2013) A novel paradigm for heart failure with preserved ejection fraction: comorbidities drive myocardial dysfunction and remodeling through coronary microvascular endothelial inflammation. J Am Coll Cardiol 62(4):263-271. doi:10. 1016/j.jacc.2013.02.092

3. van den Heuvel M, Sorop O, Koopmans SJ, Dekker R, de Vries R, van Beusekom HM, Eringa EC, Duncker DJ, Danser AH, van der Giessen WJ (2012) Coronary microvascular dysfunction in a porcine model of early atherosclerosis and diabetes. Am J Physiol Heart Circ Physiol 302(1):H85-H94. doi:10.1152/ajpheart.00311.2011

4. Paneni F, Beckman JA, Creager MA, Cosentino F (2013) Diabetes and vascular disease: pathophysiology, clinical consequences, and medical therapy: part I. Eur Heart J 34(31):2436-2443. doi:10. 1093/eurheartj/eht149

5. Vanhoutte PM (2009) Endothelial dysfunction: the first step toward coronary arteriosclerosis. Circ J 73(4):595-601

6. Jankowski V, Tolle M, Vanholder R, Schonfelder G, van der Giet M, Henning L, Schluter H, Paul M, Zidek W, Jankowski J (2005) Uridine adenosine tetraphosphate: a novel endothelium-derived vasoconstrictive factor. Nat Med 11(2):223-227. doi:10.1038/nm1188

7. Gui Y, Walsh MP, Jankowski V, Jankowski J, Zheng XL (2008) Up4A stimulates endothelium-independent contraction of isolated rat pulmonary artery. Am J Physiol Lung Cell Mol Physiol 294(4): L733-L738. doi:10.1152/ajplung.00403.2007

8. Matsumoto T, Tostes RC, Webb RC (2011) Uridine adenosine tetraphosphate-induced contraction is increased in renal but not pulmonary arteries from DOCA-salt hypertensive rats. Am J Physiol Heart Circ Physiol 301(2):H409-H417. doi:10.1152/ ajpheart.00084.2011

9. Matsumoto T, Tostes RC, Webb RC (2012) Alterations in vasoconstrictor responses to the endothelium-derived contracting factor uridine adenosine tetraphosphate are region specific in DOCA-salt hypertensive rats. Pharmacol Res 65(1):81-90. doi:10.1016/j.phrs. 2011.09.005

10. Yuan W, Wang Z, Li J, Li D, Liu D, Bai G, Walsh MP, Gui Y, Zheng XL (2013) Uridine adenosine tetraphosphate induces contraction of circular and longitudinal gastric smooth muscle by distinct signaling pathways. IUBMB Life 65(7):623-632. doi:10.1002/iub.1171

11. Zhou Z, Sun C, Tilley SL, Mustafa SJ (2015) Mechanisms underlying uridine adenosine tetraphosphate-induced vascular contraction in mouse aorta: role of thromboxane and purinergic receptors. Vasc Pharmacol 73:78-85. doi:10.1016/j.vph.2015.04.009

12. Linder AE, Tumbri M, Linder FF, Webb RC, Leite R (2008) Uridine adenosine tetraphosphate induces contraction and relaxation in rat aorta. Vasc Pharmacol 48(4-6):202-207. doi:10.1016/j. vph.2008.03.003
13. Matsumoto T, Watanabe S, Kawamura R, Taguchi K, Kobayashi T (2013) Enhanced uridine adenosine tetraphosphate-induced contraction in renal artery from type 2 diabetic Goto-Kakizaki rats due to activated cyclooxygenase/thromboxane receptor axis. Pflugers Arch. doi:10.1007/s00424-013-1330-0

14. Matsumoto T, Goulopoulou S, Taguchi K, Tostes RC, Kobayashi T (2015) Constrictor prostanoids and uridine adenosine tetraphosphate: vascular mediators and therapeutic targets in hypertension and diabetes. Br J Pharmacol 172(16):3980-4001. doi:10. 1111/bph.13205

15. Zhou Z, Merkus D, Cheng C, Duckers HJ, Jan Danser AH, Duncker DJ (2013) Uridine adenosine tetraphosphate is a novel vasodilator in the coronary microcirculation which acts through purinergic P1 but not P2 receptors. Pharmacol Res 67(1):10-17. doi:10.1016/j.phrs.2012.09.011

16. Matsumoto T, Tostes RC, Webb RC (2011) The role of uridine adenosine tetraphosphate in the vascular system. Adv Pharmacol Sci 2011:435132. doi:10.1155/2011/435132

17. Ralevic V, Burnstock G (1998) Receptors for purines and pyrimidines. Pharmacol Rev 50(3):413-492

18. Burnstock G, Novak I (2013) Purinergic signalling and diabetes. Purinergic Signal. doi:10.1007/s11302-013-9359-2

19. Burnstock G (2009) Purinergic regulation of vascular tone and remodelling. Auton Autacoid Pharmacol 29(3):63-72. doi:10.1111/j. 1474-8673.2009.00435.x

20. Ishida K, Matsumoto T, Taguchi K, Kamata K, Kobayashi T (2011) Mechanisms underlying altered extracellular nucleotide-induced contractions in mesenteric arteries from rats in later-stage type 2 diabetes: effect of ANG II type 1 receptor antagonism. Am J Physiol Heart Circ Physiol 301(5):H1850-H1861. doi:10.1152/ ajpheart.00502.2011

21. Ralevic V, Belai A, Burnstock G (1995) Effects of streptozotocindiabetes on sympathetic nerve, endothelial and smooth muscle function in the rat mesenteric arterial bed. Eur J Pharmacol 286(2):193-199

22. Thaning P, Bune LT, Hellsten Y, Pilegaard H, Saltin B, Rosenmeier JB (2010) Attenuated purinergic receptor function in patients with type 2 diabetes. Diabetes 59(1):182-189. doi:10.2337/db09-1068

23. Zhou Z, de Wijs-Meijler D, Lankhuizen I, Jankowski J, Jankowski V, Jan Danser AH, Duncker DJ, Merkus D (2013) Blunted coronary vasodilator response to uridine adenosine tetraphosphate in postinfarct remodeled myocardium is due to reduced P1 receptor activation. Pharmacol Res 77:22-29. doi:10.1016/j.phrs.2013.08.007

24. van der Velden J, Merkus D, Klarenbeek BR, James AT, Boontje NM, Dekkers DH, Stienen GJ, Lamers JM, Duncker DJ (2004) Alterations in myofilament function contribute to left ventricular dysfunction in pigs early after myocardial infarction. Circ Res 95(11):e85-e95. doi:10.1161/01.RES.0000149531.02904.09

25. Batenburg WW, Popp R, Fleming I, de Vries R, Garrelds IM, Saxena PR, Danser AH (2004) Bradykinin-induced relaxation of coronary microarteries: S-nitrosothiols as EDHF? Br J Pharmacol 142(1):125-135. doi:10.1038/sj.bjp.0705747

26. Wee S, Peart JN, Headrick JP (2007) P2 purinoceptor-mediated cardioprotection in ischemic-reperfused mouse heart. J Pharmacol Exp Ther 323(3):861-867. doi:10.1124/jpet.107.125815

27. Donnelly-Roberts DL, Namovic MT, Han P, Jarvis MF (2009) Mammalian P2X7 receptor pharmacology: comparison of recombinant mouse, rat and human P2X7 receptors. Br J Pharmacol 157(7):1203-1214. doi:10.1111/j.1476-5381.2009.00233.x

28. Sophocleous RA, Mullany PR, Winter KM, Marks DC, Sluyter R (2015) Propensity of red blood cells to undergo P2X7 receptormediated phosphatidylserine exposure does not alter during in vivo or ex vivo aging. Transfusion 55(8):1946-1954. doi:10. 1111/trf.13101

29. McGaraughty S, Chu KL, Namovic MT, Donnelly-Roberts DL, Harris RR, Zhang XF, Shieh CC, Wismer CT, Zhu CZ, Gauvin 
DM, Fabiyi AC, Honore P, Gregg RJ, Kort ME, Nelson DW, Carroll WA, Marsh K, Faltynek CR, Jarvis MF (2007) P2X7related modulation of pathological nociception in rats. Neuroscience 146(4):1817-1828. doi:10.1016/j.neuroscience. 2007.03.035

30. Baurand A, Gachet C (2003) The P2Y(1) receptor as a target for new antithrombotic drugs: a review of the P2Y(1) antagonist MRS2179. Cardiovasc Drug Rev 21(1):67-76

31. Mamedova LK, Joshi BV, Gao ZG, von Kugelgen I, Jacobson KA (2004) Diisothiocyanate derivatives as potent, insurmountable antagonists of P2Y6 nucleotide receptors. Biochem Pharmacol 67(9): 1763-1770. doi:10.1016/j.bcp.2004.01.011

32. Yang M, Soohoo D, Soelaiman S, Kalla R, Zablocki J, Chu N, Leung K, Yao L, Diamond I, Belardinelli L, Shryock JC (2007) Characterization of the potency, selectivity, and pharmacokinetic profile for six adenosine A2A receptor antagonists. Naunyn Schmiedeberg's Arch Pharmacol 375(2):133-144. doi:10.1007/ s00210-007-0135-0

33. Rondelet B, Kerbaul F, Motte S, van Beneden R, Remmelink M, Brimioulle S, McEntee K, Wauthy P, Salmon I, Ketelslegers JM, Naeije R (2003) Bosentan for the prevention of overcirculationinduced experimental pulmonary arterial hypertension. Circulation 107(9):1329-1335

34. Martino A, Cabiati M, Campan M, Prescimone T, Minocci D, Caselli C, Rossi AM, Giannessi D, Del Ry S (2011) Selection of reference genes for normalization of real-time PCR data in minipig heart failure model and evaluation of TNF-alpha mRNA expression. J Biotechnol 153(3-4):92-99. doi:10.1016/j.jbiotec.2011.04. 002

35. Jankowski V, Patzak A, Herget-Rosenthal S, Tran TN, Lai EY, Gunthner T, Buschmann I, Zidek W, Jankowski J (2008) Uridine adenosine tetraphosphate acts as an autocrine hormone affecting glomerular filtration rate. J Mol Med (Berl) 86(3):333-340. doi: 10.1007/s00109-008-0306-6

36. Hansen PB, Hristovska A, Wolff H, Vanhoutte P, Jensen BL, Bie P (2010) Uridine adenosine tetraphosphate affects contractility of mouse aorta and decreases blood pressure in conscious rats and mice. Acta Physiol (Oxf) 200(2):171-179. doi:10.1111/j.17481716.2010.02135.x

37. Zhou Z, Yadav VR, Sun C, Teng B, Mustafa JS (2016) Impaired aortic contractility to uridine adenosine tetraphosphate in angiotensin II-induced hypertensive mice: receptor desensitization? Am J Hypertens. doi:10.1093/ajh/hpw163

38. Tolle M, Schuchardt M, Wiedon A, Huang T, Klockel L, Jankowski J, Jankowski V, Zidek W, van der Giet M (2010) Differential effects of uridine adenosine tetraphosphate on purinoceptors in the rat isolated perfused kidney. Br J Pharmacol 161(3):530-540. doi:10. $1111 /$ j.1476-5381.2010.00914.x
39. Burnstock G (2010) Control of vascular tone by purines and pyrimidines. Br J Pharmacol 161(3):527-529. doi:10.1111/j.1476-5381. 2010.00937.x

40. Liu C, Mather S, Huang Y, Garland CJ, Yao X (2004) Extracellular ATP facilitates flow-induced vasodilatation in rat small mesenteric arteries. Am J Physiol Heart Circ Physiol 286(5):H1688-H1695. doi:10.1152/ajpheart.00576.2003

41. Miao LY, Tang JP, Esposito DP, Zhang JH (2001) Age-related changes in P2 receptor mRNA of rat cerebral arteries. Exp Gerontol 37(1):67-79

42. Nitenberg A, Valensi P, Sachs R, Dali M, Aptecar E, Attali JR (1993) Impairment of coronary vascular reserve and ACh-induced coronary vasodilation in diabetic patients with angiographically normal coronary arteries and normal left ventricular systolic function. Diabetes 42(7):1017-1025

43. Beyer AM, Gutterman DD (2012) Regulation of the human coronary microcirculation. J Mol Cell Cardiol 52(4):814-821. doi:10. 1016/j.yjmcc.2011.10.003

44. Zou MH, Cohen R, Ullrich V (2004) Peroxynitrite and vascular endothelial dysfunction in diabetes mellitus. Endothelium: journal of endothelial cell research 11(2):89-97. doi:10.1080/ 10623320490482619

45. Nie H, Wu JL, Zhang M, Xu J, Zou MH (2006) Endothelial nitric oxide synthase-dependent tyrosine nitration of prostacyclin synthase in diabetes in vivo. Diabetes 55(11):3133-3141. doi:10. 2337/db06-0505

46. Liu Y, Gutterman DD (2009) Vascular control in humans: focus on the coronary microcirculation. Basic Res Cardiol 104(3):211-227. doi:10.1007/s00395-009-0775-y

47. Fisslthaler B, Popp R, Kiss L, Potente M, Harder DR, Fleming I, Busse R (1999) Cytochrome P450 2C is an EDHF synthase in coronary arteries. Nature 401(6752):493-497. doi:10.1038/46816

48. Zhou Z, Hemradj V, de Beer VJ, Gao F, Hoekstra M, Merkus D, Duncker DJ (2012) Cytochrome P-450 2C9 exerts a vasoconstrictor influence on coronary resistance vessels in swine at rest and during exercise. Am J Physiol Heart Circ Physiol 302(8):H1747-H1755. doi:10.1152/ajpheart.00648.2011

49. Taverne YJ, de Beer VJ, Hoogteijling BA, Juni RP, Moens AL, Duncker DJ, Merkus D (2012) Nitroso-redox balance in control of coronary vasomotor tone. J Appl Physiol 112(10):1644-1652. doi:10.1152/japplphysiol.00479.2011

50. Gaubert ML, Sigaudo-Roussel D, Tartas M, Berrut G, Saumet JL, Fromy B (2007) Endothelium-derived hyperpolarizing factor as an in vivo back-up mechanism in the cutaneous microcirculation in old mice. J Physiol 585(Pt 2):617-626. doi:10.1113/jphysiol.2007. 143750 